\title{
BIOETHICS FROM A PRAGMATIC PERSPECTIVE: ETHICAL ISSUES IN BIOPHARMACEUTICALS
}

\author{
Michael A. Fournel ${ }^{*}$
}

\begin{abstract}
In recent times competitive, commercial and fiscal pressures have introduced new and challenging issues for the pharmaceutical industry. This essay identifies some of these issues and proposes mechanisms for their resolution. This overview is not intended to serve as a comprehensive assessment, but rather as an introduction to and call for utilization of bioethics as a tool in the resolution of practical issues that otherwise could limit the development and introduction of important therapeutic entities into the clinic.
\end{abstract}

Key words: pharmaceutical industry, ethical challenges, social behavior, drug development, safety

\section{LA BIOÉTICA DESDE UNA PERSPECTIVA PRAGMÁTICA: TEMAS ÉTICOS EN LA INDUSTRIA BIOFARMACÉUTICA}

Resumen: La industria farmacéutica ha sufrido, cada vez con mayor frecuencia, presiones fiscales, de la competencia y del comercio, que han introducido nuevos y desafiantes temas éticos. Este ensayo identifica algunos de estos temas y propone mecanismos para resolverlos. No pretendemos que éste sea un juicio abarcador, sino que sirva, más bien, como una introducción y un llamado para emplear a la bioética como un instrumento en la resolución de temas prácticos que, de otra manera, podrían limitar el desarrollo y aceptación de importantes entidades terapéuticas en su aplicación clínica.

Palabras clave: industria farmacéutica, desafíos éticos, comportamiento social, desarrollo de fármacos, seguridad

\section{A BIOÉTICA A PARTIR DE UMA PESPECTIVA PRAGMÁTICA: TEMAS ÉTICOS NA INDUSTRIA BIOFARMACÊUTICA}

Resumo: A industria farmacêutica vem sofrendo, sempre com mais frequência, pressões fiscais, da concorrência e do comercio, que introduziram novos e desafiadores temas éticos. Este ensaio identifica alguns detes temas e propõe mecanismos para resolvê-los. Não pretendemos que este seja um juizo abrangente, mas que sirva, como uma introdução e um chamado para empregar a bioética como um instrumento na resolução de temas práticos que, de outra maneira, poderiam limitar o desenvolvimento e a aceitação de importantes entidades terapêuticas em sua aplicação clínica.

Palavras chaves: industria farmacêutica, desafios éticos, comportamento social, desenvolvimento de fármacos, segurança

* Senior Vice-President of Research and Development for Bayer HealthCare's Biological Products Division. Bayer HealthCare Correspondence: Michael.fournel.b@bayer.com 
The pharmaceutical industry in general, and biopharmaceuticals specifically, is increasingly under scrutiny to perform ethically. While this has always been the case - indeed, the generic term for drugs is "ethical pharmaceutical" to reflect the higher standards applied in the development and eventual approval for use in humans - in recent times competitive, commercial and fiscal pressures have introduced new and very challenging bioethical issues for this industry. This essay identifies some of these issues and proposes mechanisms for their resolution. This overview is not intended to serve as a comprehensive assessment, but rather an introduction to and call for utilization of bioethics as a tool in the resolution of practical issues that otherwise could limit the development and introduction of important therapeutic entities into the clinic.

The emergence of the pharmaceutical industry as a dominant commercial endeavor has been fueled by several factors including innovation, successes in treating life-threatening diseases and the increasing affluence and aging of the population. With sales in excess of US $\$ 350$ billion in 2003 and multinational operations in virtually all parts of the world, this industry touches many lives in the discovery, development, regulation and commercialization of its products. Regional differences exist in all of these areas and offer opportunities for exploitation; for example, price controls exist in some countries but not others, fostering potential "gray market" importation of drugs. Some regions either lack or consciously refuse to respect intellectual property rights, allowing for generic production of drugs covered by patents. Ethical and commercial standards are very regional as are standards of care, all of which present potential for misuse.

Against this background exists a need in the pharmaceutical industry to minimize risks and investments required for the development of new drugs: where opportunity exists to do so there is a compelling case to utilize such opportunities to facilitate and even expedite drug development. Further complicating this ethical landscape is the evolution of ethical requirements in industrialized countries, at times presenting onerous, and not always reasonable expectations upon an industry, which is still attempting to test hypotheses and failing more often than succeeding in identifying new and novel therapies.

For purposes of discussion, the ethical issues mentioned above can be considered to fall within three broad categories:

\section{Business Ethics}

Examples of issues under this heading would be commercial activities, contracts and pricing, incentives and kickbacks, issues of good faith and fairness, liabilities and litigation. Perhaps the most advanced in terms of mitigation, many mechanisms already exist to address opportunities for commercial exploitation. For example, industry and corporate standards have been published by most large companies and internal mechanisms such as ethics ombudsman, active compliance and ethics training have been established. More importantly, companies need to establish and vigorously defend a corporate culture and ethical philosophy to ensure compliance. Regulatory and legal protections are also in place in many countries, including anti-trust, competitive surveillance and legislation to thwart efforts to exploit differences. As recent problems in other industries have illustrated, the need for more comprehensive legislation to ensure fiduciary compliance has been recognized. Consumer and governmental advocacy is a major factor influencing business to perform according to ethical standards: the power of public exposure of unethical behaviors often drives companies to reform well before legislative actions are required; oversight of the industries by governmental agencies similarly identifies and rec- 
tifies issues. While abuses will continue to occur, this combination of self-regulation, governmental controls and consumer advocacy has been instrumental in minimizing unethical conduct.

\section{Ethical Social Behavior}

This category includes more subtle yet important aspects of ethical behavior not easily addressed by the mechanisms discussed above. Examples would include the openness of information sharing, risk mitigation for patients and customers, and local investment.

Openness of information sharing. In the past, ownership of information generated in a clinical trial was assumed to be exclusive to the company providing the financial support for the development. However, this information was gathered by healthcare professionals from patients who volunteered to participate, often with little or no remuneration and potentially subjected to life-endangering procedures or placebo treatments for their disease. Questions about data manipulation, objectivity in assessments and representation, and access to learnings to guide future medical research have arisen from such restricted ownership of trial results.

Risk mitigation for patients and customers. The determination of the efficacy of a new drug is increasingly well managed as improvements in diagnoses, detection and understanding of pathology is applied to clinical assessments. The same is not the case for safety since untoward effects may not be seen with adequate frequency in a clinical trial setting. Relatively rare or infrequent adverse drug reactions may only become evident after thousands or more uses of a given drug. The balance between reasonable expectations for assessment of potential side effects against desire to introduce a new therapy requires careful consideration so as to minimize risks to patients while maximizing the utilization of important therapeutic options.
Local investment. Also a subject under the next category, the issue of return of the benefits from commercialization of a drug to the communities in which it was studied presents an ethical challenge since failure to do so opens the consideration of exploitation. Yet, often the standards of care in a region make the new therapy unaffordable to the healthcare system.

Mitigation of social behavior violations is much more difficult since it requires primarily a mandate from consumer and advocacy groups for good corporate citizenship. In this regard, patient organizations like the World Hemophilia Foundation have been effective in requiring industry to meet minimum requirements to support and protect patients. Ultimately, the business model requires sustainability and this drives the need for social responsibility (Rand's objectivism is a powerful concept beyond regulation in this regard). Industry would do well to make investments in this arena to allow for debate and balanced recommendations for standards and resolution of complex issues. One such example has been the Bayer International Bioethics Advisory Council.

\section{Ethical Drug Development}

This third area represents a fascinating, evolving and important aspect of this bioethics environment. A few examples will serve to illustrate the category:

Use of patients in countries without intention to market. A very controversial topic, driven by a variety of forces, the potential for exploitation needs to be weighed against the need to conduct clinical trials under standards which may not be available in all countries. For example, testing of an already licensed drug for a new indication for which no comprehensive medical proof exists of efficacy yet it is already in use (so-called off-label indications) requires a placebo control. Yet, in countries where the standard of care already in- 
cludes usage of the drug for the indication, the medical community will consider it unethical to subject a patient to a placebo arm. Testing in countries where this standard does not exist avoids this ethical dilemma, but successful demonstration of efficacy may present a financial burden to the local health care budget.

Trial design issues. Related to the above, often drug development requires demonstration of improvement over the existing standard of care to justify drug licensure. In regions where that standard is very high this represents a hurdle with increased risk for the development versus testing in a region with a lower standard. If the therapy ultimately cannot be marketed in that region, the ethical implications need to be measured against the advance of therapeutic options for the disease.

Safety standards, quality of care. It has been recognized for some time that exploitation of regional differences in such regards presents ethical dilemmas yet existing standards may not be adequate as medical research advances into previously unconsidered areas.

Post-trial treatment. If a therapy demonstrates utility in the clinical setting, what is the obligation/expectation for the sponsor to continue to provide access to the drug to trial participants after the trial closes? This is especially pertinent in those regions where eventual marketing of the therapy is not planned or uncertain.

While some steps have been taken to establish standards for the ethical treatment of clinical trial subjects (e.g., the Declaration of Helsinki (WMA) and International Conferences on Harmonization), many of these issues are emerging beyond the scope of those efforts. Scientific/ medical society positions are increasingly important in this regard as are local Institutional Ethical Committees, although these often do not enter into the broader debate represented by some of the issues mentioned. Most important has been public debate of the issues, whether in sponsored forums and scientific meetings, by patient advocacy groups or expert opinions offered by institutions like the Bayer International Bioethics Advisory Council.

Important to all of the above is the realization that there are inherent problems in establishing mitigation for an industry. Alignment amongst companies is generally difficult to achieve due to competitive pressures, often only occurring at a lowest common denominator level. Additionally, there are regulatory hurdles to such cooperation, often a consequence of good intentions to prevent negative collusion (e.g., anti-trust, price-fixing). The public perception is often different, assuming all companies within an industry have similar objectives and interactions. This is fostered by media reports of exceptional behaviors that are assumed to be the norm. Achieving a competitive advantage often outweighs any desire for alignment since shortterm financial objectives increasingly compete against long-term vision. As a result it is even more imperative for industry leaders to drive the alignment process since only they can hold these competing forces in check. The mechanisms for collaboration on important bioethical issues need to be isolated from competitive pressures.

This overview of bioethical issues affecting the pharmaceutical industry hopefully illustrates that these issues are too significant and complex to be left to chance for resolution. Bioethical forums need to be supported to provide the platform for discussions and recommendations: they also need to become pragmatic and practical to have influence over current issues. It is essential that the experts are independent from bias, so the support for such platforms should not have any commercial ties (i.e., public or non-commercial funding). The bioethics community should lead this effort but will likely find ready support from allied specialties including the medical and scientific environment. 